\title{
An Update of the Definition of Transfusion-Related Acute Lung Injury
}

\author{
Transfüzyon Illişkili Akut Akciğer Hasarının Tanımında Güncelleme
}

(D) Alexander P.J. Vlaar¹, (D) Steve Kleinman²

1 Academic Medical Centre, Department of Intensive Care, Amsterdam, The Netherlands

2University British Columbia, Department of Pathology, Vancouver, Canada

To the Editor,

In the past transfusion-related acute lung injury (TRALI) was regarded as a rare complication of transfusion medicine. Subsequently, TRALI has been shown to be one of the leading causes of transfusion-related morbidity and mortality. Insight into TRALI pathogenesis in the past decades has resulted in the development of preventive strategies [1]. The accumulation of clinical and basic science knowledge has provided the rationale for a recent update of the widely used 2004 Canadian Consensus Conference (CCC) definition of TRALI (Table 1) [2]. A panel of 10 international experts on TRALI, including two members with hemovigilance expertise, used the Delphi panel approach to develop a redefinition of TRALI by modifying the 2004 CCC definition [3].

The updated TRALI definition along with the rationale for the changes has now been published (Table 2) [3]. The main

\begin{tabular}{|c|c|c|c|c|}
\hline \multirow[t]{10}{*}{ TRALI } & \multirow[t]{7}{*}{ a. } & i. & $\begin{array}{l}\text { Acute } \\
\text { onset }\end{array}$ & \\
\hline & & \multirow[t]{4}{*}{ ii. } & Hypoxemia & Research setting: \\
\hline & & & & $\begin{array}{l}\mathrm{PaO}_{2} / \mathrm{FiO}_{2} \leq 300 \\
\text { or } \mathrm{SpO}_{2}<90 \% \text { on room air }\end{array}$ \\
\hline & & & & Non-research setting: \\
\hline & & & & $\begin{array}{l}\mathrm{PaO}_{2} / \mathrm{FiO}_{2} \leq 300 \\
\text { or } \mathrm{SpO}_{2}<90 \% \text { on room air } \\
\text { or other clinical evidence } \\
\text { of hypoxemia }\end{array}$ \\
\hline & & iii. & \multicolumn{2}{|c|}{ Bilateral infiltrates on chest radiograph } \\
\hline & & iv. & \multicolumn{2}{|c|}{$\begin{array}{l}\text { No evidence of left atrial hypertension and/or } \\
\text { Central venous pressure }<18 \mathrm{mmHg}\end{array}$} \\
\hline & b. & \multicolumn{3}{|c|}{ No preexisting ALI before transfusion } \\
\hline & c. & \multicolumn{3}{|c|}{ During or within 6 hours of transfusion } \\
\hline & d. & \multicolumn{3}{|c|}{$\begin{array}{l}\text { No temporal relationship to an alternative risk } \\
\text { factor for ALI }\end{array}$} \\
\hline \multirow{2}{*}{$\begin{array}{l}\text { Possible } \\
\text { TRALI }\end{array}$} & a. & \multicolumn{3}{|c|}{ As mentioned above } \\
\hline & b. & \multicolumn{3}{|c|}{ In the presence of an alternative risk factor for ALI } \\
\hline
\end{tabular}

modifications are as follows: 1) The term "possible TRALI" has been dropped. 2) TRALI has been separated into two types: TRALI type I (without an acute respiratory distress syndrome (ARDS) risk factor) and TRALI type II (with an ARDS risk factor or with mild preexisting ARDS). Notably, the presence of either an ARDS risk factor or mild ARDS does not exclude the diagnosis of TRALI as it

Table 2. New consensus TRALI definition [3].

TRALI type I - Patients who have no risk factors for ARDS and meet the following criteria:

\begin{tabular}{|c|c|c|c|}
\hline \multirow[t]{4}{*}{ a. } & i. & Acute onset & \\
\hline & ii. & Hypoxemia & $\begin{array}{l}\mathrm{PaO}_{2} / \mathrm{FiO}_{2} \leq 300^{*} \\
\text { or } \mathrm{SpO}_{2}<90 \% \text { on room air }\end{array}$ \\
\hline & iii. & \multicolumn{2}{|c|}{$\begin{array}{l}\text { Clear evidence of bilateral pulmonary edema on } \\
\text { imaging (e.g., chest radiograph, chest CT, or ultrasound }\end{array}$} \\
\hline & iv. & \multicolumn{2}{|c|}{$\begin{array}{l}\text { No evidence of left atrial hypertension }{ }^{* *} \text { or, if LAH is } \\
\text { present, it is judged to not be the main contributor to } \\
\text { the hypoxemia }\end{array}$} \\
\hline b. & \multicolumn{3}{|c|}{ Onset during or within 6 hours of transfusion ${ }^{* * *}$} \\
\hline e. & \multicolumn{3}{|c|}{$\begin{array}{l}\text { No temporal relationship to an alternative risk factor for } \\
\text { ARDS }\end{array}$} \\
\hline
\end{tabular}

TRALI type II - Patients who have risk factors for ARDS (but who have not been diagnosed with ARDS) or who have preexisting mild ARDS $\left(\mathrm{PaO}_{2} / \mathrm{FiO}_{2}\right.$ of $\left.200-300\right)$, but whose respiratory status deteriorates ${ }^{* * *}$ and is judged to be due to transfusion based on:

a. Findings as described in categories $a$ and $b$ of TRALI type I, and

b. Stable respiratory status in the 12 hours prior to transfusion

*If altitude is higher than $1000 \mathrm{~m}$, the correction factor should be calculated as follows: $\left[\left(\mathrm{PaO}_{2} / \mathrm{FiO}_{2}\right) \times\right.$ (barometric pressure/760)].

**Use objective evaluation when LAH is suspected (imaging, e.g., echocardiography, or invasive measurement using, e.g., pulmonary artery catheter).

${ }^{* * *}$ Onset of pulmonary symptoms (e.g., hypoxemia - lower $\mathrm{P} / \mathrm{F}$ ratio or $\mathrm{SpO}_{2}$ ) should be within 6 hours of end of transfusion. The additional findings needed to diagnose TRALI (pulmonary edema on a lung imaging study and determination of lack of substantial $\mathrm{LAH}$ ) would ideally be available at the same time but could be documented up to 24 hours after TRALI onset

*** Use $\mathrm{PaO}_{2} / \mathrm{FiO}_{2}$ ratio deterioration along with other respiratory parameters and clinical judgement to determine progression from mild to moderate or severe ARDS. See the conversion table in Appendix S2 of the original report to convert nasal $\mathrm{O}_{2}$ supplementation to $\mathrm{FiO}_{2}[3]$ 
did under the old definition. 3) Cases with an ARDS risk factor that meet ARDS diagnostic criteria and where respiratory deterioration over the 12 hours prior to transfusion implicates the risk factor as causative should be classified as ARDS rather than TRALI type II. 4) The 2012 updated ARDS consensus definition (referred to as the BERLIN definition) has been evaluated for its relevance to TRALI and essential updates (including guidance in diagnosing hydrostatic pulmonary edema) have been incorporated into the new TRALI definition.

More broadly, the Delphi panel recommended that all pulmonary complications after blood transfusion should be reported to the transfusion service and then categorized (either by the transfusion service, a hospital transfusion committee, or a hemovigilance system) into one of several categories: TRALI (type I or type II), ARDS, transfusion-associated circulatory overload (TACO), TRALI/ TACO - cannot distinguish, or an alternate diagnosis. Importantly, the panel reaffirmed that TRALI remains a clinical diagnosis and does not require detection of cognate leukocyte antibodies, though it did recommend that these data be captured through a hemovigilance reporting system. Future research directions have been identified and include identifying the mechanism behind the onset of TRALI in the absence of cognate leukocyte antibodies. Furthermore, the panel is working on developing a universal reporting form for posttransfusion pulmonary complications including suspected TRALI.

We believe that the TRALI definition update is such an important change for transfusion medicine that it needs to be widely disseminated and discussed. To this end, the panel has submitted this letter to the editors of several important transfusion and hemovigilance journals $[4,5]$. We hope that the new definition contributes to an enhanced level of reporting and a more accurate classification of respiratory complications associated with blood transfusion.

Keywords: TRALI, Definition, Delphi

Anahtar Sözcükler: TRALI, Tanım, Delphi

Conflict of Interest: The authors of this paper have no conflicts of interest, including specific financial interests, relationships, and/or affiliations relevant to the subject matter or materials included.

\section{References}

1. Semple JW, Rebetz J, Kapur R. Transfusion-associated circulatory overload and transfusion-related acute lung injury. Blood 2019;133:1840-1853.

2. Kleinman $S$, Caulfield $T$, Chan $P$, Davenport $R$, McFarland J, McPhedran S, Meade M, Morrison D, Pinsent T, Robillard P, Slinger P. Toward an understanding of transfusion-related acute lung injury: statement of a consensus panel. Transfusion 2004;44:1774-1789.

3. Vlaar APJ, Toy P, Fung M, Looney MR, Juffermans NP, Bux J, Bolton-Maggs $P$, Peters AL, Silliman CC, Kor DJ, Kleinman S. A consensus redefinition of transfusion-related acute lung injury. Transfusion 2019;59:2465-2476.

4. Vlaar APJ, Toy P, Fung M, Looney MR, Juffermans NP, Bux J, Bolton-Maggs $P$, Peters AL, Silliman CC, Kor DJ, Kleinman S. An update of the transfusionrelated acute lung injury (TRALI) definition. Transfus Clin Biol (in press). doi: 10.1016/j.tracli.2019.05.007.

5. Vlaar APJ, Kleinman S. An update of the transfusion-related acute lung injury (TRALI) definition. Transfus Apher Sci (in press). doi: 10.1016/j. transci.2019.07.011.

${ }^{\circ}$ Copyright 2019 by Turkish Society of Hematology

Turkish Journal of Hematology, Published by Galenos Publishing House 